\title{
TINJAUAN YURIDIS TERHADAP POLIS ELEKTRONIK DALAM PERJANJIAN ASURANSI
}

\author{
Vianda Karina Ika Putri ${ }^{1}$, Bambang Winarno ${ }^{2}$, A. Rachmad Budiono ${ }^{3}$ \\ Program Studi Magister Ilmu Hukum \\ Fakultas Hukum Universitas Brawijaya \\ Email : viandakarina@gmail.com
}

\begin{abstract}
Electronic policy or e-policy is an insurance contract that happends due to an electronic commercial transactions. But e-policy has been in Indonesia although there is no clear legal framework related to the existence of these e-policy. The purpose of this study are 1) Determine and analyze how the legality of e-policy according to the law in Indonesia. 2) Determine and analyze how the strength of e-policies evidence in the event of a dispute between the parties. Judicial review of electronic policy in the insurance agreement, namely: 1) E-polis as a form of agreement which could be interpreted is not qualify as legitimate epolicy agreement contrary to KUHDagang to be equivalent for sub law. So, insurance agreement can be interpreted is not meet objective conditions of an agreement that could result in the agreement is null and void (Article 1320 of KUHPerdata). 2) The strength of evidence on e-policy will have a strong legal force if the e-policy is made in the form of a deed in writing and acknowledged by both parties entered into an agreement, but if epolicy just softfile that send by email then e-policy does not have the strength of evidence because it was not in accordance with the provisions of Indonesian laws.
\end{abstract}

Keywords: Agreement, E-policy, The Insurance Agreement

\begin{abstract}
Abstrak: Polis elektronik atau e-polis merupakan kontrak asuransi yang terjadi akibat suatu transaksi komersial elektronik. Namun e-polis telah berada di Indonesia meski belum ada payung hukum yang jelas terkait adanya e-polis ini. Tujuan Penelitian ini ialah 1) Mengetahui dan menganalisis keabsahan e-polis menurut hukum di Indonesia, 2) Mengetahui dan menganalisis bagaimana kekuatan pembuktian e-polis dalam hal terjadi sengketa antara para pihak. Tinjauan yuridis terhadap polis elektronik dalam perjanjian asuransi, yakni : 1) E-polis sebagai suatu bentuk perjanjian yang dapat diartikan tidak memenuhi syarat sah perjanjian karena e-polis bertentangan dengan KUHDagang yang setara dengan Undang-Undang. Sehingga perjanjian asuransi tersebut dapat diartikan tidak memenuhi syarat objektif suatu perjanjian yang dapat mengakibatkan perjanjian tersebut batal demi hukum (Pasal 1320 KUHPerdata). 2) Kekuatan pembuktian pada e-polis akan memiliki kekuatan hukum yang kuat apabila e-polis dibuat dalam bentuk akta yang tertulis dan diakui oleh kedua belah pihak yang mengadakan perjanjian, namun apabila e-polis tersebut hanya berbentuk softfile yang dikirim melalui email maka e-polis tersebut tidak memiliki kekuatan pembuktian karena tidak sesuai dengan ketentuan-ketentuan hukum positif Indonesia.
\end{abstract}

Kata Kunci : Perjanjian, E-polis, perjanjian asuransi

\footnotetext{
${ }^{1}$ Mahasiswa, Program Studi Magister Ilmu Hukum, Fakultas Hukum Universitas Brawijaya, Malang.

${ }^{2}$ Dosen Pembimbing I, Dosen Fakultas Hukum Universitas Brawijaya Malang.

${ }^{3}$ Dosen Pembimbing II, Dosen Fakultas Hukum Universitas Brawijaya Malang.
} 


\section{Latar Belakang}

Pada zaman globalisasi, Komputer sebagai alat bantu manusia dengan didukung perkembangan teknologi informasi, telah membantu akses ke dalam jaringan-jaringan publik (public network) dalam melakukan pemindahan data dan informasi, dengan kemampuan komputer dan akses yang semakin berkembang, maka transaksi perdagangan pun dilakukan di dalam jaringan komunikasi tersebut. Jaringan publik mempunyai keunggulan dibandingkan dengan jaringan privat dengan adanya efisiensi biaya dan waktu, hal ini membuat perdagangan dengan transaksi elektronik (Electronic Commerce) menjadi pilihan bagi para pelaku bisnis untuk melancarkan transaksi perdagangannya.

Transaksi elektronik bersifat non face (tanpa bertatap muka), non sign (tidak memakai tanda tangan asli) dan tanpa batas wilayah (seseorang dapat melakukan transaksi elektronik dengan pihak lain walaupun mereka berada di Negara yang berbeda) dengan menggunakan teknologi informasi. Kemudahan yang ditawarkan teknologi membuat transaksi elektronik berkembang pesat. Hal ini tidak terbatas pada perdagangan barang saja namun sudah berkembang pada perdagangan jasa. Pemanfaatan teknologi informasi dalam bisnis asuransi salah satunya menghasilkan polis elektronik atau e-polis. E-polis merupakan dokumen polis asuransi dalam bentuk elektronik yang diterbitkan oleh perusahaan asuransi kepada nasabah berisi kontrak perjanjian.

Dalam Undang-Undang No 40 Tahun 2014 tentang Perasuransian yang dimaksud dengan asuransi adalah perjanjian antara dua pihak, yaitu perusahaan asuransi dan pemegang polis. Sehingga asuransi adalah perjanjian tanggung menanggung antara tertanggung dan penanggung yang aktanya disebut polis asuransi. Kebutuhan akan perlindungan atau jaminan asuransi bersumber dari keinginan untuk mengatasi ketidakpastian. Ketidakpastian mengandung risiko yang dapat menimbulkan ancaman bagi setiap pihak, baik pribadi maupun sebagai pelaku bisnis. Risiko yang timbul dapat bersumber dari bencana alam, kecelakaan, penyakit, kelalaian, ketidakmampuan, kesalahan, kegagalan, ataupun dari berbagai sebab-sebab lain yang dapat diduga sebelumnya termasuk tindakan kerusuhan, sabotase, dan terorisme. Masingmasing risiko mungkin memerlukan bentuk penanganan yang berbeda. ${ }^{4}$

Kontrak asuransi sangat spesifik karena hanya ditandatangani oleh penanggung (perusahaan asuransi), tetapi

4 A. Junaedy Ganie, Hukum Asuransi Indonesia,Sinar Grafika, Jakarta, 2013, Hlm.2 
mengikat tertanggung. Isi perjanjian umumnya disusun oleh perusahaan asuransi menjadi sesuatu yang baku atau standar. Pada praktiknya sering terjadi permasalahan antara tertanggung dan penanggung. Kontrak asuransi merupakan suatu kontrak yang sensitif. Hal ini karena yang dijadikan objek dalam perjanjian tersebut merupakan suatu ketidakpastian.

Pengakuan kontrak elektronik sebagai suatu bentuk perjanjian dalam Kitab Undang-Undang Hukum Perdata (KUH Perdata) Indonesia masih merupakan permasalahan yang pelik. Pasal 1313 KUH Perdata mengenai definisi perjanjian memang tidak menentukan bahwa suatu perjanjian harus dibuat secara tertulis. Pasal 1313 KUH Perdata hanya menyebutkan bahwa perjanjian adalah suatu perbuatan dengan mana satu orang atau lebih mengikatkan dirinya terhadap satu orang lain atau lebih.

Asuransi merupakan salah satu bentuk perjanjian sebagaimana dalam KUHPerdata. Dalam Pasal 255 Kitab Undang-Undang Hukum Dagang (KUHD) menyatakan bahwa :

"Pertanggungan harus dilakukan secara tertulis dengan akta, yang diberi nama polis. (KUHD 256.)".

Hal ini berarti polis harus dilakukan secara tertulis, namun demikian semakin pesatnya perkembangan teknologi membuat kebutuhan akan adanya transaksi yang mudah, cepat, dan murah telah membuat beberapa Perusahaan asuransi menawarkan e-polis sebagai salah satu upaya menarik konsumen. Kemudahan bertransaksi melalui internet yang terkesan mudah dan efisien sangat menguntungkan Perusahaan Asuransi dan juga konsumen (tertanggung). Sedangkan dalam regulasi terbaru terkait Undang-Undang Nomor 40 tahun 2014 tentang Perasuransian tidak terdapat definisi dari Polis. Pengertian dari polis hanya terdapat pada Kitab Undang-Undang Hukum Dagang. Beberapa Perusahaan Asuransi di Indonesia telah memasarkan epolis meski belum ada payung hukum yang jelas terkait adanya e-polis ini. Efisiensi biaya operasional dan biaya cetak menjadi alasan utama beberapa Perusahaan Asuransi di Indonesia menerbitkan e-polis.

Sejak tahun 1999 Rancangan Undang-Undang Informasi dan Transaksi Elektronik dibahas oleh Badan Legislatif yang berwenang, akhirnya Indonesia mempunyai aturan hukum untuk mengatur masalah tersebut dengan dikeluarkannya Undang-Undang Nomor 11 tahun 2008 tentang Informasi dan Transaksi Elektronik yang disahkan pada tanggal 21 April 2008. Namun demikian Undang-Undang tersebut tidak mengatur secara spesifik mengenai $e$ polis. 
Dengan demikian sampai saat ini masih belum terdapat Peraturan perundangundangan yang menjadi dasar hukum e-polis ini. Apalagi apabila kemudian terjadi perselisihan antara penanggung dan tertanggung yang memakai e-polis. Berdasarkan uraian tersebut, beberapa permasalahan pokok yang akan diteliti antara lain sebagai berikut : 1) Bagaimana keabsahan e-polis menurut hukum di Indonesia?, 2) Bagaimana kekuatan pembuktian suatu e-polis?

\section{Pembahasan}

\section{Keabsahan Polis Elektronik Menurut}

Hukum di Indonesia.

Kemampuan komputer dan akses yang semakin berkembang, maka transaksi perdagangan pun dilakukan di dalam jaringan komunikasi tersebut. $\mathrm{Hal}$ ini membuat perdagangan dengan transaksi elektronik (Electronic Commerce) menjadi pilihan bagi para pelaku bisnis untuk melancarkan transaksi perdagangannya. Transaksi elektronik bersifat non face (tanpa bertatap muka) yang tanpa batas wilayah (seseorang dapat melakukan transaksi elektronik dengan pihak lain walaupun mereka berada di Negara yang berbeda). Pemanfaatan teknologi informasi dalam bisnis asuransi salah satunya menghasilkan polis elektronik atau e-polis.

Polis elektronik atau e-polis merupakan kontrak asuransi yang terjadi akibat suatu transaksi komersial elektronik. Pada era sekarang telah banyak transaksi yang menggunakan media elektronik. Tidak hanya terbatas pada perdagangan barang namun juga jasa yang diperdagangkan melalui transaksi elektronik. Polis asuransi salah satunya, telah dilakukan melalui transaksi elektronik. Keuntungan bagi nasabah dengan menggunakan polis elektronik adalah mempersingkat waktu serta biaya sedangkan keuntungan bagi perusahaan asuransi tentu saja memotong biaya operasional.

Pada proses penerbitan e-polis kurang lebih sama dengan penerbitan polis pada umumnya. Namun demikian terdapat beberapa perbedaan. Perbedaan yang pertama adalah pada saat pembelian produk pembeli tidak menerima penjelasan dari marketing namun lebih kepada uraian informasi dalam website saja. Selanjutnya perbedaan kedua adalah ketika proses underwriting. Underwriting merupakan proses seleksi risiko. Analisis atas risiko dilakukan untuk menentukan premi yang akan dibayarkan oleh tertanggung nantinya (tergantung seberapa besar risiko yang dimiliki oleh tertanggung).

Selanjutnya, pada proses akhir yaitu penerbitan polis asuransi. Apabila biasanya polis akan dicetak dan dikirimkan kepada tertanggung melalui kurir maka dalam proses penerbitan e-polis yang telah selesai 
Jurnal Syariah: Jurnal Imu Hukum dan Pemikiran Vol. 17, Nomor 1, Juni 2017

tersebut tidak dicetak namun akan dikirimkan kepada tertanggung melalui email. Polis yang dikirimkan penanggung kepada tertanggung berbentuk soft file.

Pada dasarnya e-polis juga merupakan bentuk dari perjanjian yang pada umumnya telah diatur dalam pasal 1313 KUHPerdata :

"Perjanjian adalah suatu perbuatan dengan mana satu orang atau lebih mengikatkan dirinya terhadap satu orang atau lebih.”

Sebab kesepakatan atau kata sepakat merupakan bentukkan atau merupakan unsur dari suatu perjanjian (Overeenkomst) yang bertujuan menciptakan suatu keadaan dimana para pihak yang mengadakan perjanjian mencapai suatu kesepakatan atau tercapainya suatu kehendak. Kata sepakat dalam suatu perjanjian dapat diperoleh melalui suatu proses penawaran (offerte) dan penerimaan (acceptatie).

Teori keabsahan merupakan titik awal dalam menjelaskan validasi dari tindakan perjanjian e-polis. Keabsahan berasal dari kata sah yang dalam bahasa Inggris disebut dengan legal. Legal dalam kamus Oxford diartikan dengan based on the law ${ }^{5}$, sedangkan dalam Black's Law Dictionary kata Legal diartikan of relating to law, established, required or permitted by law, of or relating to law as opposed

5 Oxford Learn's Pocket Dictionary, Fourth Edition, (United Kingdom: Oxford University Press, 2008), hlm. 251.
Tinjauan Yuridis Terhadap ....115-132

Vianda Karina dke.

to equity. ${ }^{6}$ Dalam kata bahasa Indonesia dapat diartikan menurut undang-undang. Ini berarti bahwa kata sah diartikan dengan sesuatu yang sesuai dengan ketentuan undang-undang.

Agar perjanjian asuransi yang dilakukan menggunakan media elektronik dapat dikatakan sah menurut hukum perdata Indonesia, maka perjanjian tersebut harus memenuhi syarat sah perjanjian menurut Pasal 1320 KUHPerdata tersebut.

Selain syarat sah perjanjian yang disebutkan dalam Pasal 1320 KUHPerdata terdapat pula syarat perjanjian asuransi berdasarkan KUHDagang karena perjanjian asuransi memiliki kekhususan. Berdasarkan Pasal 246 KUHDagang menyatakan bahwa

"Asuransi atau pertanggungan adalah perjanjian, dimana penanggung mengikat diri terhadap tertanggung dengan memperoleh premi, untuk memberikan kepadanya ganti rugi karena suatu kehilangan, kerusakan, atau tidak mendapat keuntungan yang diharapkan, yang mungkin akan dapat diderita karena suatu peristiwa yang tidak pasti. (KUHPerdatad. 1774; KUHD 60, 249, 252, 269, 286, 593.)"

6 Henry Black Campbell, Black's Law Dictionary, Seventh Edition, (Saint Paul: West Grup, 1979), hlm. 902. 
Jurnal Syariah: Jurnal Ilmu Hukum dan Pemikiran Vol. 17, Nomor 1, Juni 2017

Selanjutya berdasarkan Pasal 255 Kitab Undang-Undang Hukum Dagang menyatakan bahwa

"Pertanggungan harus dilakukan secara tertulis dengan akta, yang diberi nama polis. (KUHD 256)"

Dengan demikian kekhususan dari perjanjian asuransi adalah bahwa perjanjian tersebut harus dilakukan secara tertulis dengan akta yang kemudian disebut polis. Pengertian tertulis sendiri dalam Kitab Undang-Undamg Hukum Dagang tidak terdapat penjelasan lebih lanjut. Dalam Kitab Undang-Undang Hukum Dagang dijelaskan lebih lanjut mengenai apa yang harus tercantum dalam polis, Pasal 256 Kitab Undang-Undang Hukum Perdata.

Peraturan perundang-undangan yang mengatur asuransi hanya terdapat dalam KUHDagang dan KUHPerdata yang mengatur perjanjian secara umum. Sedangkan Undang-Undang No.40 tahun 2014 mengatur mengenai Perasuransian. Ketentuan polis terdapat dalam KUHDagang merupakan Peraturan Perundang-undangan peninggalan kolonial Belanda sehingga ketika dipakai untuk menerapkan permasalahan saat ini sudah tidak sesuai lagi.

Perkembangan pesat teknologi informasi begitu juga dalam dunia asuransi menimbulkan permasalahan baru yang tidak
Tinjanan Yuridis Terhadap ....115-132

Vianda Karina dke.

hanya bisa diselesaikan dengan menggunakan KUHDagang karena pada saat itu belum dikenal adanya teknologi informasi semacam itu. Saat ini berkembang pula dalam dunia asuransi polis elektronik. Dengan adanya polis elektronik ini sebenarnya lebih bermanfaat karena proses pembuatan polis akan lebih cepat serta lebih memudahkan nasabah.

Menurut kamus besar bahasa Indonesia pengertian Tulis adalah ada huruf (angka dsb) yang dibuat (digurat dsb) dengan pena (pensil, cat, dsb); bersurat (yang sudah disetujui); yang ada tulisannya: piagam yg berupa tembaga. Sedangkan pengertian tertulis yaitu (sudah) ditulis; tersurat; termaktub. Pengertian Written Contract menurut black law dictionary : "A "written contract" is one which in all its terms is in writing."

Kontrak tertulis adalah semua syarat dan ketentuan yang ditulis. Sedangkan pengertian writing menurut black law dictionary adalah :

"In the most general sense of the word, "writing" denotes a document, whether manuscript or printed, as opposed to mere spoken words. Writing is essential to the validity of certain contracts and other transactions." 
Pada arti yang paling umum dari kata, "writing" menunjukkan dokumen, apakah naskah atau dicetak, sebagai lawan kata yang diucapkan belaka. Tulisan adalah penting untuk keabsahan kontrak tertentu dan transaksi lainnya.

Sehingga pengertian tertulis yang dinyatakan dalam Pasal 255 Kitab UndangUndang Hukum Dagang "Pertanggungan harus dilakukan secara tertulis dengan akta, yang diberi nama polis" memiliki pengertian tertulis di atas kertas (hitam diatas putih). Berdasarkan pengertian-pengertian diatas dapat disimpulkan bahwa tertulis baik yang merupakan tulisan tangan maupun hasil cetak. Sesuatu yang ditulis dengan tangan atau dicetak diatas kertas.

Selanjutnya, mengingat KUHDagang tersebut warisan dari Pemerintah Belanda yang masih berlaku hingga saat ini sehingga dapat diperkirakan bahwa pada zamannya pengertian tertulis yang dimaksud dalam KUHDagang merupakan hitam diatas putih karena pada saat itu belum terdapat media elektronik.

Berdasarkan pengertian tertulis diatas maka perjanjian asuransi yang menggunakan e-polis dapat diartikan pula tidak sesuai dengan Undang-Undang yaitu Pasal 255 KUHDagang karena e-polis yang digunakan dalam perjanjian asuransi tidak sesuai dengan makna tertulis yang dimaksudkan KUHDagang. Sehingga e-polis tersebut tidak memenuhi syarat sah perjanjian yang ke empat yaitu causa yang halal. Walaupun pada dasarnya, hukum perjanjian di Indonesia menganut asas kebebasan berkontrak (Pasal 1338 KUHPerdata). Dalam hal ini setiap pihak yang mengadakan perjanjian bebas membuat perjanjian sepanjang isi perjanjian tersebut tidak bertentangan dengan prinsip-prinsip hukum yang berlaku, tidak melanggar kesusilaan dan ketertiban umum (lihat Pasal 1337 KUHPerdata). Sedangkan perjanjian asuransi menggunakan e-polis bertentangan dengan KUHDagang yang setara dengan Undang-Undang. Sehingga perjanjian asuransi tersebut dapat diartikan tidak memenuhi syarat objektif suatu perjanjian yang dapat mengakibatkan perjanjian tersebut batal demi hukum.

Namun demikian perlu diingat Pasal 257 ayat 1 KUHDagang menentukan bahwa perjanjian pertanggungan ada segera setelah diadakan, hak-hak dan kewajibankewajiban timbal balik dari tertanggung dan penanggung mulai sejak saat itu, bahkan sebelum polis ditandatangani. Pasal 257 KUHD menyatakan bahwa perjanjian pertanggungan itu bersifat konsensualisme akan tetapi Pasal 255 KUHD mengharuskan pembuatan perjanjian pertanggungan itu dalam suatu akta yang disebut polis. Sehingga polis merupakan 
Jurnal Syariah: Jurnal Imu Hukum dan Pemikiran Vol. 17, Nomor 1, Juni 2017

tanda bukti adanya perjanjian pertanggungan.

Melihat Pasal 257 ayat

KUHDagang yang menyatakan bahwa perjanjian pertanggungan sudah mulai berlaku bahkan sebelum polis ditandatangi. Hal ini berarti bahwa perjanjian pertanggungan menganut asas konsensualisme. Asas konsensualisme menentukan bahwa suatu perjanjian yang dibuat antara dua atau lebih orang telah mengikat sehingga telah melahirkan kewajiban bagi salah satu atau lebih pihak dalam perjanjian tersebut, segera setelah orang tersebut mencapai kesepakatan atau konsesus, meskipun kesepakatan telah dicapai secara lisan semata-mata. Ini berarti pada prinsipnya perjanjian yang mengikat dan berlaku sebagai perikatan bagi para pihak berjanji tidak memerlukan formalitas. Walaupun demikian untuk menjaga kepentingan para pihak diperlukan bukti tertulis bahwa perjanjian tersebut telah terjadi.

Pada prakteknya perjanjian asuransi yang dibuat oleh perusahaan asuransi dengan tertanggung saat ini tidak akan terjadi klaim kecuali apabila tertanggung dapat menunjukan polis atau cover note yang dimiliki. Apabila tertanggung melakukan klaim tanpa membawa bukti tertulis berupa polis asuransi maka perjanjian yang dibuat dengan penanggung
Tinjauan Yuridis Terhadap ....115-132

Vianda Karina dke

tersebut akan sulit dibuktikan eksistensinya. Dengan demikian tetap dibutuhkan suatu bukti tertulis yang menyatakan telah terjadinya suatu perjanjian.

Perjanjian asuransi menggunakan $e$ polis pada dasarnya telah memenuhi syarat sah perjanjian sesuai dengan yang terdapat pada KUHPerdata seperti yang telah disebutkan diatas. Namun demikian e-polis tersebut tidak sesuai dengan Pasal 255 KUHDagang. Perjanjian asuransi merupakan suatu bisnis kepercayaan. Perjanjian ini tidak akan terjadi tanpa adanya kepercayaan kedua belah pihak. Perjanjian asuransi baru sah apabila penutupannya didasari dengan itikad baik (Pasal 251 KUHDagang). Perjanjian asuransi merupakan perjanjian yang digantungkan pada sesuatu peristiwa yang belum pasti sehingga dalam hal ini itikad baik dan rasa saling percaya diantara para pihak sangat penting. Oleh sebab itu dibuatnya perjanjian asuransi dalam bentuk tertulis yaitu polis sangat penting untuk melindungi kepentingan para pihak apabila terjadi perselisihan di kemudian hari.

Selanjutnya Pasal 264 KUHDagang menentukan, selain mengadakan perjanjian asuransi untuk kepentingan diri sendiri, juga diperbolehkan mengadakan perjanjian asuransi untuk kepentingan pihak ketiga, baik berdasarkan pemberian kuasa kepada pihak ketiga ataupun diluar pengetahuan 
pihak ketiga yang berkepentingan. masyarakat untuk melakukan upaya Tertanggung dalam melaksanakan perjanjian pemberdayaan konsumen melalui asuransi mempunyai hak dan kewajiban pembinaan dan pendidikan konsumen. yang harus dilaksanakan, sehingga apabila terjadi peristiwa yang tidak diharapkan yang terjamin kondisi polis maka penanggung dapat melaksanakan kewajibannya. Sehingga keberadaan polis sangat penting dalam perjanjian asuransi.

Pada perjanjian asuransi yang lazim dilakukan oleh tertanggung dan perusahaan asuransi sekarang ini sering digunakan perjanjian baku yang dibuat oleh perusahaan. Alasan digunakannya perjanjian baku dalam perjanjian asuransi adalah untuk mempersingkat waktu dan menyederhanakan bentuk perjanjian itu sendiri. Sehingga tertanggung tidak perlu repot untuk memikirkan isi perjanjian. Namun demikian, dengan adanya kontrak baku perjanjian sekarang ini banyak konsumen yang dirugikan dengan klausula yang ada dalam perjanjian tersebut.

Atas dasar kelemahan konsumen tersebut, maka diperlukan adanya payung hukum yang kuat yang dapat digunakan untuk memberdayakan konsumen, melindungi kepentingan konsumen secara integratif dan komprehensif serta dapat diterapkan secara efektif di masyarakat. Adanya undang-undang tersebut juga dapat digunakan oleh pemerintah dan lembaga perlindungan konsumen swadaya Tertanggung sebagai pihak yang lemah memerlukan perlindungan hukum dari Negara. Pada dasarnya tertanggung merupakan konsumen sehingga tertanggung dilindungi oleh Undang-Undang Nomor 8 Tahun 1999 tentang Perlindungan Konsumen.

Perjanjian asuransi antara tertanggung dan perusahaan asuransi menggunakan perjanjian baku dalam membuat kesepakatan dengan tertanggung. Perusahaan asuransi berposisi sebagai pelaku usaha, sedangkan tertanggung berposisi sebagai konsumen. Perusahaan asuransi sebagai pelaku usaha didasarkan pada pengertian pelaku usaha pada Pasal 1 angka 3 Undang-undang Nomor 8 Tahun 1999 tentang Perlindungan Konsumen bahwa Pelaku usaha adalah setiap orang perseorangan atau badan usaha, baik yang berbentuk badan hukum maupun bukan badan hukum yang didirikan dan berkedudukan atau melakukan kegiatan dalam wilayah hukum negara Republik Indonesia, baik sendiri maupun bersamasama melalui perjanjian menyelenggarakan kegiatan usaha dalam berbagai bidang ekonomi. Sedangkan tertanggung sebagai konsumen didasarkan pada Pasal 1 angka 2 Undang-undang Nomor 8 Tahun 1999 
Jurnal Syariah: Jurnal Imu Hukum dan Pemikiran Vol. 17, Nomor 1, Juni 2017

tentang Perlindungan Konsumen bahwa Konsumen adalah setiap orang pemakai barang dan/atau jasa yang tersedia dalam masyarakat, baik bagi kepentingan diri sendiri, keluarga, orang lain maupun makhluk hidup lain dan tidak untuk diperdagangkan. Kedua pihak tersebut mengikatkan diri dalam perjanjian asuransi bahwa perusahaan asuransi berjanji untuk menanggung risiko yang akan terjadi oleh tertanggung sedangkan tertanggung wajib membayar sejumlah uang yang telah disepakati diantara keduanya.

Pada dasarnya perjanjian tersebut harus dilaksanakan berdasarkan kesepakatan bebas antara kedua pihak yang cakap untuk bertindak demi hukum (pemenuhan syarat subjektif) untuk melaksanakan suatu prestasi yang tidak bertentangan dengan aturan hukum yang berlaku, kepatutan, kesusilaan, ketertiban umum serta kebiasaan yang berlaku dalam masyarakat luas (pemenuhan syarat objektif). ${ }^{7} \quad$ Namun, terkadang perjanjian yang dibentuk membuat ketidak seimbangan kedudukan kedua pihak yang berakibat pada tidak memberikan keuntungan bagi salah satu pihak.

Berdasarkan Pasal 2 Undang-Undang Nomor 8 Tahun 1999 menyatakan bahwa:

\footnotetext{
7 Abdul Halim Barkatullah, Hukum Perlindungan Konsumen: Kajian Teoretis dan Perkembangan Pemikiran, FH Unlam Press, Banjarmasin, hlm. 95.
}

\section{Tinjauan Yuridis Terhadap ....115-132 \\ Vianda Karina dke.}

Perlindungan konsumen berasaskan manfaat, keadilan, keseimbangan, keamanan dan keselamatan konsumen, serta kepastian hukum.

Untuk itu perlu ditingkatkan salah satu tujuan diselenggarakannya perlindungan konsumen yaitu asas kepastian hukum. Polis merupakan salah satu bukti penting untuk melindungi konsumen dan membuktikan perjanjian asuransi itu sendiri. Tanpa adanya tatap muka dan bentuk polis yang dikirimkan berupa softfile melalui email maka dalam polis itu sendiri tidak dapat dicantumkan materai. Padahal dalam Pasal 2 Undang-Undang 13 Tahun 1985 telah menjelaskan mengenai macam-macam dokumen yang dikenakan Bea Materai.

Dengan demikian polis termasuk dokumen yang dikenakan materai. Sedangkan Dokumen yang dimaksud dalam Pasal 1 ayat (2) huruf a Undang-Undang Nomor 13 Tahun 1985 tentang Bea Materai adalah

"Dokumen adalah kertas yang berisikan tulisan yang mengandung arti dan maksud tentang perbuatan, keadaan atau kenyataan bagi seseorang dan/atau pihakpihak yang berkepentingan;"

Dengan demikian e-polis yang merupakan dokumen elektronik tidak dapat dibebankan bea materai. Pada prakteknya 
Jurnal Syariah: Jurnal Imu Hukum dan Pemikiran Vol. 17, Nomor 1, Juni 2017

karena $e$-polis dikirimkan oleh sistem melalui kepada tertanggung langsung melalui email maka tidak terdapat materai pada e-polis tersebut.

Suatu penjanjian apabila tidak terdapat materai di dalamnya pada dasarnya masih sah karena syarat sah suatu perjanjian adalah sesuai dengan Pasal 1320 KUHPerdata. Tidak adanya materai tidak membuat suatu perjanjian menjadi tidak sah. Azas kepastian hukum yang tercantum dalam Pasal 2 Undang-Undang Nomor 8 Tahun 1999 tentang Perlindungan Konsumen dimaksudkan agar baik pelaku usaha maupun konsumen menaati hukum dan memperoleh keadilan dalam penyelenggaraan perlindungan konsumen, serta negara menjamin kepastian hukum.

Berdasarkan hal-hal tersebut diatas salah satu hak konsumen adalah untuk mendapat informasi yang benar, jelas dan jujur mengenai kondisi dan jaminan barang dan/ atau jasa. Memang pada prakteknya deskripsi produk asuransi itu sendiri akan dimuat di website Perusahaan. Namun demikian pengetahuan masyarakat Indonesia yang sangat minim akan asuransi besar kemungkinan tertanggung tidak memahami dengan seksama terkait dengan produk asuransi tersebut. Sehingga perlu penjelasan tenaga pemasar dari perusahaan asuransi tersebut. Dalam prakteknya tenaga pemasar asuransi harus memiliki sertifikat
Tinjauan Yuridis Terhadap ....115-132

Vianda Karina dke

dari asosiasi asuransi. Kurangnya pemahaman dari tertanggung besar kemungkinan menyebabkan dispute dikemudian hari. Dengan kedudukan konsumen yang berada pada pihak yang lemah kiranya perlindungan konsumen asuransi perlu lebih ditingkatkan lagi.

\section{Kekuatan E-Polis sebagai Alat Bukti}

Pembuktian merupakan satu aspek yang memegang peranan sentral dalam suatu proses peradilan. Pada kasus pidana, nasib terdakwa akan ditentukan pada tahap ini, jika tidak cukup alat bukti, terdakwa akan dinyatakan tidak bersalah dan harus dibebaskan, begitupun sebaliknya. Sedangkan pada kasus perdata, dalam tahap pembuktian ini para pihak diberikan kesempatan untuk menunjukkan kebenaran terhadap fakta-fakta hukum yang merupakan titik pokok sengketa Sehingga, hakim yang memeriksa dan memutus perkara akan mendasarkan pada alat bukti yang diajukan oleh para pihak yang bersengketa.

Pembuktian merupakan suatu cara yang dilakukan oleh suatu pihak untuk meyakinkan hakim tentang kebenaran dalil atau dalil-dalil yang dikemukakan dalam suatu persengketaan dan bertujuan untuk memberikan kepastian mengenai fakta hukum yang menjadi pokok sengketa untuk kemudian dijadikan dasar bagi suatu 
Jurnal Syariah: Jurnal Imu Hukum dan Pemikiran Vol. 17, Nomor 1, Juni 2017

putusan hakim. Menurut Sistem HIR, dalam hukum acara perdata hakim terikat pada alat-alat bukti yang sah, yang artinya hakim hanya boleh memutuskan perkara melalui alat bukti yang telah ditentukan sebelumnya oleh undang-undang. Alat-alat bukti yang disebutkan oleh undang-undang.

Pada perjanjian asuransi konvensional polis dibuat secara tertulis dan ditanda tangani oleh penanggung. Hal ini untuk mempermudah pembuktian apabila terjadi sengketa mengenai perjanjian asuransi tersebut. Namun untuk polis elektronik (epolis) yang dilakukan tanpa tatap muka antara para pihak, bukti atas transaksi tersebut tersimpan dalam bentuk data elektronik yang terekam dalam sistem penyimpanan data komputer serta polis yang berbentuk softfile yang dikirimkan dalam bentuk email. Dalam hal ini timbul permasalahan mengenai kekuatan pembuktian e-polis tersebut sebagai alat bukti dalam hal terjadi sengketa antara para pihak.

Salah satu aspek penting dalam perjanjian asuransi menggunakan e-polis adalah pemahaman hukum atas suatu e-polis sehingga e-polis tersebut memiliki kedudukan dan kekuatan pembuktian yang sama sebagaimana hukum tertulis. Sistem hukum pembuktian dalam hukum perdata di Indonesia sampai saat ini masih menggunakan ketentuan dalam Pasal 1865 sampai dengan Pasal 1945 KUHPerdata,
Tinjauan Yuridis Terhadap ....115-132

Vianda Karina dke
Pasal 137 sampai dengan Pasal 158 dan Pasal 162 sampai dengan Pasal 177 HIR (untuk Jawa dan Madura) serta Pasal 163 sampai dengan sampai dengan Pasal 185 dan Pasal 282 sampai dengan Pasal 314 Rbg(untuk luar Jawa dan madura). Menurut ketentuan-ketentuan tersebut, alat-alat bukti dalam hukum pembuktian perdata yang berlaku di Indonesia adalah Alat bukti surat atau tulisan, Alat bukti saksi, Alat bukti persangkaan, Alat bukti pengakuan, Alat bukti sumpah.

Dari semua alat bukti tersebut, dalam hukum acara perdata alat bukti tulisan mendapat tempat yang utama. Pada praktiknya, suatu perjanjian harus dibuat secara tertulis dan ditandatangani. Hal ini adalah untuk mempermudah pembuktian apabila terjadi sengketa mengenai perjanjian tersebut.

Berdasarkan pasal 1868 KUHPerdata, bukti tertulis/ tulisan ini merupakan suatu bentuk akta di bawah tangan, bukan akta otentik karena tidak dibuat oleh atau di hadapan pejabat umum yang berwenang.

Polis asuransi merupakan salah satu bentuk akta dibawah tangan karena tidak dibuat dihadapan pejabat umum yang berwenang. Polis asuransi dibuat oleh para pihak saja dengan ditambahkan materai pada perjanjian tersebut karena polis pada dasarnya dibuat sebagai alat bukti apabila 
dikemudian hari terjadi sengketa. Demikian halnya dengan e-polis pada dasarnya sama dengan polis pada umunya hanya haja e-polis memiliki bentuk yang berbeda yaitu berupa dokumen elektronik yang dibuat oleh sistem. Yang membedakan dengan polis biasa pada e-polis tidak terdapat materai.

$\begin{array}{rrr}\text { Mengenai } & \text { daya } & \text { kekuatan } \\ \text { pembuktiannya, } & \text { Yahya } & \text { Harahap }\end{array}$
menyebutkan bahwa untuk Akta di Bawah Tangan memiliki 2 (dua) jenis daya kekuatan yang melekat padanya yaitu:

a. Daya Kekuatan Pembuktian Formil;

1. Orang yang bertanda tangan dianggap benar menerangkan hal yang tercantum dalam akta;

2. Tidak mutlak untuk keuntungan pihak lain

b. Daya Pembuktian Materiil.

1. Isi keterangan yang tercantum harus dianggap benar;

2. Memiliki daya mengikat kepada ahli waris dan orang yang mendapat hak dari padanya;

Apabila para pihak telah memenuhi ketentuan-ketentuan tersebut di atas, yaitu para pihak telah mengakui kebenaran akta/ polis tersebut, maka polis tersebut memiliki kekuatan pembuktian yang sempurna dan mengikat berdasarkan Pasal 1875 KUHPerdata.

Berdasarkan Pasal 255 KUHD, perjanjian asuransi harus dibuat secara tertulis dalam bentuk akta yang disebut dengan "Polis". Selain itu, berdasarkan Pasal 19 ayat (1) PP No. 73 Tahun 1992 tentang Penyelenggaraan Usaha

Perasuransian menyatakan bahwa:

"Polis atau bentuk perjanjian asuransi dengan nama apapun, berikut lampiran yang merupakan kesatuan dengannya, tidak boleh mengandung kata-kata, atau kalimat yang dapat menimbulkan penafsiran yang berbeda mengenai risiko yang ditutup asuransinya, kewajiban penanggung dan kewajiban tertanggung, atau mempersulit tertanggung mengurus haknya"

Menurut Prof. Abdulkadir Muhammad, S.H., berdasarkan ketentuan dua Pasal tersebut di atas, maka dapat diketahui bahwa polis berfungsi sebagai alat bukti tertulis bahwa telah terjadi perjanjian asuransi antara tertanggung dan penanggung. Sebagai alat bukti tertulis, isi yang tercantum dalam polis harus jelas, tidak boleh mengandung kata-kata atau kalimat yang memungkinkan perbedaan interpretasi sehingga mempersulit tertanggung dan penanggung merealisasikan hak dan kewajiban mereka dalam pelaksanaan asuransi. Di samping itu, polis juga memuat kesepakatan mengenai syaratsyarat khusus dan janji-janji khusus yang menjadi dasar pemenuhan hak dan kewajiban untuk mencapai tujuan asuransi. ${ }^{8}$ Menurut Ali Rido, polis adalah suatu akta

${ }^{8}$ Prof. Abdulkadir Muhammad, S.H., dalam bukunya "Hukum Asuransi Indonesia" (hal. 58), 
Jurnal Syariah: Jurnal Imu Hukum dan Pemikiran Vol. 17, Nomor 1, Juni 2017

yang ditandatangani oleh penanggung, yang fungsinya sebagai alat bukti dalam perjanjian asuransi. Sedangkan Molenggraf mengatakan polis adalah suatu akta sebagai tulisan sepihak, dimana diuraikan dengan syarat-syarat apa penanggung menerima perjanjian asuransi.

$$
\text { Pada perjanjian asuransi }
$$
menggunakan e-polis perjanjian asuransi dilaksanakan dengan menggunakan media elektronik tanpa tatap muka antara para pihak. Bukti atas transaksi tersebut berupa softfile e-polis yang dikirimkan melalui email.

Hakim dalam memeriksa suatu perkara tidak boleh menolak memeriksa suatu perkara dengan alasan tidak ada hukumnya (ius curia novit). Sehingga dimungkinkan bagi hakim untuk melakukan interpretasi otentik agar suatu e-polis dapat diterima sebagai alat bukti dalam perkara perdata. Namun demikian dalam memeriksa hukum acara perdata hakim terikat pada alat-alat bukti yang sah dan tidak diperkenankan melakukan penafsiran. Hal ini berkaitan dengan sifat dari kebenaran yang dicari dalam suatu perkara perdata, yaitu kebenaran formal serta dengan ketentuan bahwa alat bukti dalam perkara perdata bersifat limitatif sehingga tidak memungkinkan hakim melakukan penafsiran diluar apa yang telah ditentukan Undang-Undang. Maka berdasarkan ketentuan ini maka e-polis dapat dikategorikan tidak memenuhi syarat bukti tertulis dan masih sulit diterima sebagai alat bukti dalam persidangan. Dengan demikian, apabila terjadi sengketa maka harus digunakan alat bukti yang lain seperti keterangan saksi.

Indonesia telah melakukan upaya untuk mengatasi pembuktian yang berkaitan dengan transaksi elektronik. Hal tersebut terdapat pada pasal 5 hingga 9 UndangUndang Nomor 11 Tahun 2008 tentang Informasi dan Transaksi Elektronik.

Berdasarkan ketentuan-ketentuan diatas Penanggung (dalam hal ini perusahaan asuransi) berusaha memenuhi kriteria dalam Undang-Undang Nomor 11 Tahun 2008 tentang Informasi dan Transaksi Elektronik tersebut. Perusahaan asuransi telah menyediakan informasi atas produk yang ditawarkan. Informasi produk tersebut dimuat dalam website perusahaan asuransi. Suatu informasi elektronik dan/atau dokumen elektronik dan/atau hasil cetaknya dapat menjadi alat bukti hukum yang sah karena merupakan perluasan dari alat bukti yang sah sesuai dengan Hukum Acara Perdata yang berlaku di Indonesia. Brian A. Prastyo menegaskan UU ITE telah mempertegas print out sebagai alat bukti. Menunjuk pada 5 ayat (1), dimana dirumuskan: informasi elektronik dan/atau dokumen elektronik dan/atau 
Jurnal Syariah: Jurnal Imu Hukum dan Pemikiran Vol. 17, Nomor 1, Juni 2017

hasil cetaknya merupakan alat bukti hukum yang sah.

Namun demikian terdapat pengecualian dalam Pasal 5 ayat (4) Undang-Undang Nomor 11 Tahun 2008 tentang Informasi dan Transaksi Elektronik yang menyatakan bahwa:

"Ketentuan mengenai Informasi Elektronik dan/atau Dokumen Elektronik sebagaimana dimaksud pada ayat (1) tidak berlaku untuk:

a. Surat yang menurut Undang-Undang harus dibuat dalam bentuk tertulis; dan

b. Surat beserta dokumennya yang menurut Undang-Undang harus dibuat dalam bentuk akta notaril atau akta yang dibuat oleh pejabat pembuat akta"

Berdasarkan pemaparan diatas, pada hakekatnya tujuan pembuktian adalah untuk menghasilkan suatu putusan atau untuk menghasilkan suatu penetapan. Jadi, tujuan pembuktian adalah putusan hakim yang didasarkan pada pembuktian itu. Sebagai tujuan akhir dari pembuktian itu harus sesuai dengan tujuan dari hukum pada umumnya. Sehingga kekuatan pembuktian pada e-polis akan memiliki kekuatan hukum yang kuat apabila e-polis tersebut dibuat dalam bentuk akta yang tertulis dan diakui oleh kedua belah pihak, namun apabila e-
Tinjauan Yuridis Terhadap ....115-132

Vianda Karina dke

polis tersebut hanya berbentuk soffile yang dikirim melalui email maka e-polis tersebut tidak memiliki kekuatan pembuktian karena tidak sesuai dengan ketentuan-ketentuan hukum positif Indonesia.

\section{Kesimpulan}

1. Berdasarkan Pasal 1320 KUHPerdata, E-polis sebagai suatu bentuk perjanjian pada umumnya telah memenuhi syarat sahnya perjanjian berdasarkan Pasal 1320 KUHPerdata. Namun demikian sebagai sebagai suatu bentuk perjanjian e-polis juga diatur dalam KUHDagang. Sedangkan berdasarkan Pasal 255 KUHDagang pertanggungan harus dilakukan secara tertulis dengan akta, yang diberi nama polis. Sehingga e-polis dapat diartikan tidak memenuhi syarat sah perjanjian yang ke empat yaitu causa yang halal karena e-polis bertentangan dengan KUHDagang yang setara dengan Undang-Undang. Sehingga perjanjian asuransi tersebut dapat diartikan tidak memenuhi syarat objektif suatu perjanjian yang dapat mengakibatkan perjanjian tersebut batal demi hukum. Namun demikian perlu diingat Pasal 257 ayat 1 KUHDagang menentukan bahwa perjanjian pertanggungan ada segera setelah diadakan, hak-hak dan kewajiban-kewajiban timbal balik dari 
Jurnal Syariah: Jurnal Imu Hukum dan Pemikiran Vol. 17, Nomor 1, Juni 2017

tertanggung dan penanggung mulai sejak saat itu, bahkan sebelum polis ditandatangani. Polis penting sebagai suatu bentuk penerapan perlindungan konsumen yang mana merupakan amanat Undang-Undang Nomor 8 Tahun 1999 tentang Perlindungan Konsumen serta sebagai alat bukti apabila terjadi sengketa diantara para pihak.

2. Kekuatan pembuktian pada e-polis akan memiliki kekuatan hukum yang kuat apabila e-polis dibuat dalam bentuk akta yang tertulis dan diakui oleh kedua belah pihak yang mengadakan perjanjian, namun apabila e-polis tersebut hanya berbentuk softfile yang dikirim melalui email maka e-polis tersebut tidak memiliki kekuatan pembuktian karena tidak sesuai dengan ketentuanketentuan hukum positif Indonesia.

\section{Saran}

1. Bagi pemerintah

a. Untuk mengantisipasi semakin berkembangnya dunia bisnis asuransi melalui media elektronik dan untuk menjamin kepastian hukum e-polis maka pemerintah sebaiknya segera merevisi KUHDagang karena KUHDagang sudah tidak sesuai dengan
Tinjauan Yuridis Terhadap ....115-132

Vianda Karina dke.

perkembangan zaman. Pengertian polis dalam KUHDagang sudah tidak sesuai dengan perkembangan dunia bisnis saat ini.

b. Dalam membuat peraturan hendaknya Pemerintah menjadikan UNCITRAL Model law on Electronic Commerce 1996 sebagai salah satu bahan pertimbangan.

c. Dalam membuat peraturan hendaknya pemerintah memperhatikan harmonisasi antar Pasal serta antar Peraturan Perundang-Undangan yang terkait, dalam hal misalnya seperti UndangUndang Nomor 13 Tahun 1985 tentang Bea Materai dan UndangUndang Nomor 8 Tahun 1999 tentang Perlindungan Konsumen.

2. Bagi Industri Asuransi

Agar perusahaan asuransi di Indonesia membuat kajian yang lebih mendalam terkait dengan e-polis sehingga e-polis dapat berlaku dan memberi kepastian hukum bagi para pihak.

3. Bagi Konsumen/ tertanggung Agar konsumen/ tertanggung lebih teliti ketika membeli polis asuransi agar ketika klaim tidak terjadi masalah. 


\section{Daftar Pustaka}

Abdul Halim Barkatullah, Hukum

Perlindungan Konsumen: Kajian

Teoretis dan Perkembangan

Pemikiran, FH Unlam Press,

Banjarmasin.

A. Junaedy Ganie, Hukum Asuransi

Indonesia,Sinar Grafika, Jakarta, 2013.

Henry Black Campbell, Black's Law Dictionary, Seventh Edition, (Saint Paul: West Grup, 1979).

Kitab Undang-Undang Hukum Dagang.

Kitab Undang-Undang Hukum Perdata.

Oxford Learn's Pocket Dictionary, Fourth

Edition, (United Kingdom: Oxford

University Press, 2008).

Undang-Undang Nomor 13 Tahun 1985

tentang Bea Materai.

Undang-Undang Nomor 8 Tahun 1999

tentang Perlindungan Konsumen.

Undang-Undang No.11 Tahun 2008 tentang Informasi dan Transaksi Elektronik

Undang-Undang No.40 Tahun 2014 tentang Perasuransian.

Peraturan Pemerintah Nomor 73 Tahun 1992 tentang Penyelenggaraan Usaha Perasuransian. 